\title{
Mechanisms of pulmonary fibrosis: role of activated myofibroblasts and NADPH oxidase
}

\author{
Victor J Thannickal \\ From Fibroproliferative disorders: from biochemical analysis to targeted therapies \\ Frauenchiemsee, Germany. 25-30 September 2010
}

\begin{abstract}
A common feature of pathological fibrosis involving the lung and other organs is the persistent activation of myofibroblasts in injured tissues. Recent evidence supports the role of a member of the NADPH oxidase (NOX) gene family, NOX4, in myofibroblast differentiation, matrix synthesis and contractility. Additionally, NOX4 may contribute directly or indirectly to alveolar epithelial cell death, while myofibroblasts themselves acquire an apoptosis-resistant phenotype. Thus, NOX4 may be responsible for the cardinal features of progressive fibrosis myofibroblast activation and epithelial cell dysrepair. Therapeutic targeting of NOX4 is likely to be effective in progressive cases of fibrosis involving multiple organs.
\end{abstract}

\section{Introduction}

Fibrosis of mammalian tissues/organs is perhaps best understood as an evolutionarily conserved, adaptive tissue response to injury. In most pathological scenarios when tissue fibrosis is observed, there appears to be an associated impairment in regeneration of the adjacent airway/ luminal epithelium or vascular endothelium. Natural selection appears to have favored the development of fibrosis at sites of wounding or injury, at the expense of complete restoration of tissue architecture and function. It makes teleological sense that the more immediate need for survival of the organism from bleeding and infection would take precedence over a temporary (often reversible), and often marginal, loss of organ functions. Indeed in multiple plant and animal species, formations of extracellular matrix (ECM) "scars" around traumatic, non-infectious and/or infectious injury are "normal" responses that serve to limit the invasion/spread of the pathogen at the site of injury/infection [1]. An illustrative example of this tissue response in humans is in the formation of a fibrotic scar around Mycobacterium tuberculosis bacilli, without which an estimated third of world's population infected with this infectious agent would not be expected to survive for very

Correspondence: vjthan@uab.edu

Division of Pulmonary, Allergy and Critical Care Medicine, University of

Alabama at Birmingham, 1530 3rd Avenue South, THT 422, Birmingham, AL 35294-0006, USA long [2]. Thus, fibrosis may be considered as part of innate host defense mechanisms against infection, or the perceived threat of infection (non-infectious injury). The enigma in many human highly lethal fibrotic disorders, in particular idiopathic pulmonary fibrosis (IPF), is the current, lack of understanding of: (1) the etiology of the apparent injury/infection, and (2) the progressive nature of the fibrotic process. Here, I address these issues with a greater focus on the second problem related to fibrosis progression and a potential role for NOX4 in this process.

\section{Etiological considerations in IPF}

Pulmonary fibrosis results from a large number of known causes (e.g. organic and inorganic dust exposures); however, a specific etiological agent in IPF has not been identified [3]. A number of risk factors have been identified; these include inhalational exposures, including cigarette smoking, gastroesophageal reflux, diabetes mellitus, and advanced age. Given the natural course of the disease and the epidemiologcal data supporting the concept that IPF is an age-associated disease [4], one possibility is that this results from a failure of "maintenance regeneration" due to a combination of chronic, subclinical insults in a subset of genetically-susceptible, elderly patients (Figure 1). Indeed, telomerase mutations have been identified in familial IPF [5,6], and shortened telomeres appear to be a risk factor for sporadic IPF [7]. Fibrosis associated with 


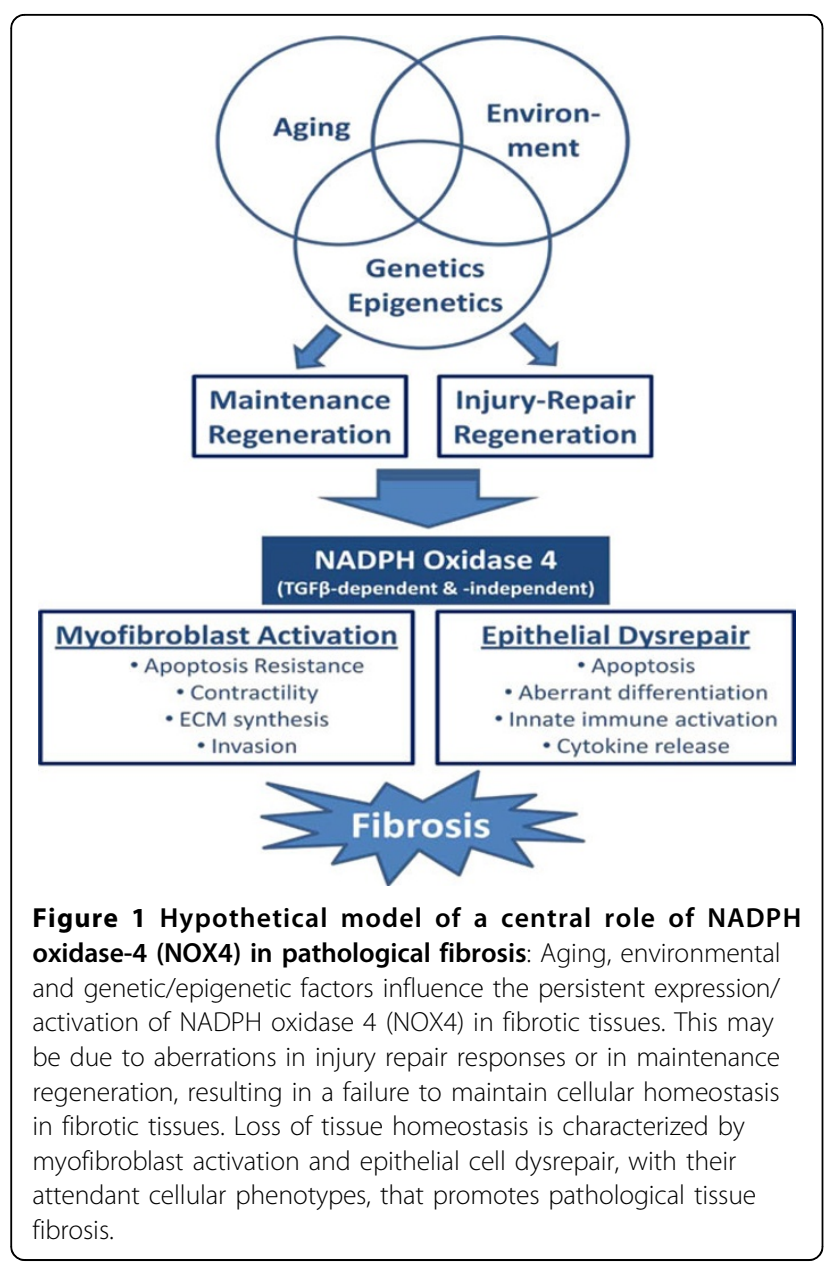

"injury-provoked regeneration" which may be easier to recognize clinically due to the relative acuteness of disease onset and progression, as in diseases such as hypersensitivity pneumonitis.

\section{Fibrosis progression: persistence of tissue myofibroblasts}

While a number of acute/subacute lung injuries that result in fibrosis are at least partially reversible, IPF is not. A key feature of these clinical syndromes in diverse organ systems is the persistence of tissue myofibroblasts in actively remodeling tissues. The local activation of tissue myofibroblasts are a highly conserved and stereotypic response to injury [8], and is fundamental to a broader biological principle in development, maintenance, and injury-repair responses of mammalian tissues/organs perpetual and dynamic epithelial-mesenchymal-endothelial interactions.

In the repair response to injury, activation of local myofibroblast precursors occurs early and their disappearance is a hallmark of fibrosis resolution [9]. Mechanisms that lead to myofibroblast apoptosis in physiologic wound- repair, however, remain unclear; it has been postulated that cross-linking of a contracted ECM shields myofibroblasts from biomechanical stress and that loss of mechanical tension may induce myofibroblast apoptosis $[8,10,11]$. Similarly, the mechanisms of an apparent "apoptosis-resistant" myofibroblast phenotype in progressive fibrotic disorders, including IPF, are not well defined [12]. The presence, activation, and survival of myofibroblasts in fibrotic tissues explains several morphological, physiological, and clinical features, including the "fibrocontractive" nature of histopathological changes characterized by alveolar collapse, reduced lung compliance, restrictive physiology, and progression.

Our studies have demonstrated that, in addition to myofibroblast differentiation, the pro-fibrotic cytokine, transforming growth factor- $\beta 1$ (TGF- $\beta 1$ ), promotes myofibroblast differentiation [13]. TGF- $\beta 1$ activates two pro-survival signaling pathways, focal adhesion kinase (FAK) and protein kinase $\mathrm{B}$ (PKB/AKT) by mechanisms that involve cell adhesion and release of soluble growth factors, respectively $[13,14]$; both pathways contribute combinatorially to myofibroblast survival [15]. Importantly, the administration of a protein kinase inhibitor that modulates the activities of these pro-survival pathways attenuates fibrosis in a model of bleomycin-induced lung fibrosis [16]. Further studies of the potential role of these pathways as a common mechanism of apoptosis resistance of myofibroblasts in IPF or in individualized patients requires further study.

More recent studies from our laboratory support the role of a member of the NADPH oxidase (NOX) family, NOX4, in myofibroblast differentiation/survival. NOX4 was identified as one of the most highly upregulated genes in transcriptomal (Affymetrix) analyses of human lung fibroblasts treated with TGF- $\beta 1$ [17]. NOX4 activation mediates generation of hydrogen peroxide $\left(\mathrm{H}_{2} \mathrm{O}_{2}\right)$, myofibroblast differentiation, contractility, and ECM production in response to TGF- $\beta 1$, effects that also seen in human IPF-derived (myo)fibroblasts [17]. In human tissues of IPF patients, the expression of NOX4 is localized to myofibroblasts, both within fibroblastic foci and in remodeled blood vessels, as well as in epithelial cells associated aberrant bronchiolization [17]. Therapeutic targeting of this NOX isoform protects against fibrosis in two different animal models of injury-provoked pulmonary fibrosis [17]. Work by other investigators suggest that NOX4 may play a pro-fibrotic role by inducing apoptosis of lung epithelial cells [18]. Epithelial cell death may also be mediated indirectly by the paracrine secretion of $\mathrm{H}_{2} \mathrm{O}_{2}$ by activated myofibroblasts [19]. These observations, in addition to the purported role of NOX4 in vascular remodeling [20,21], suggest that NOX4 mediates effects on multiple cell types and tissue compartments that contribute to organ fibrosis. 


\section{Conclusion}

Progressive fibrotic disorders are associated with an apoptosis-resistant myofibroblast phenotype. The mechanisms that give rise to this myofibroblast phenotype may include the acquisition of pro-survival signaling pathways and expression/activation of NOX4. Paradoxically, activation of NOX4 and generation of extracellular $\mathrm{H}_{2} \mathrm{O}_{2}$ may promote the death of adjacent epithelial cells [19], setting up a feed-forward mechanism for fibrosis linked to impairments in epithelial regenerative capacity that would lead to progressive fibrosis. Targeting molecules and signaling pathways that promote survival of myofibroblasts represents a promising therapeutic strategy in clinical syndromes characterized by progressive of fibrosis, including IPF.

\section{Acknowledgements}

This article has been published as part of Fibrogenesis \& Tissue Repair Volume 5 Supplement 1, 2012: Proceedings of Fibroproliferative disorders: from biochemical analysis to targeted therapies. The full contents of the supplement are available online at http://www.fibrogenesis.com/ supplements/5/S1.

This work was funded by National Institutes of Health grants, HL067967 and HL107181.

\section{Competing interests}

The author declares that they have no competing interests.

Published: 6 June 2012

\section{References}

1. Levine $A$, Tenhaken $\mathrm{R}$, Dixon $\mathrm{R}$, Lamb $\mathrm{C}: \mathrm{H}_{2} \mathrm{O}_{2}$ from the oxidative burst orchestrates the plant hypersensitive disease resistance response. Cell 1994, 79:583-593.

2. Jasmer RM, Nahid P, Hopewell PC: Clinical practice. Latent tuberculosis infection. N Engl J Med 2002, 347:1860-1866.

3. Thannickal VJ, Toews GB, White ES, Lynch JP, Martinez FJ: Mechanisms of pulmonary fibrosis. Annu Rev Med 2004, 55:395-417.

4. Raghu G, Weycker D, Edelsberg J, Bradford WZ, Oster G: Incidence and prevalence of idiopathic pulmonary fibrosis. Am J Respir Crit Care Med 2006, 174:810-816.

5. Armanios MY, Chen JJ, Cogan JD, Alder JK, Ingersoll RG, Markin C, Lawson WE, Xie M, Vulto I, Phillips JA, Lansdorp PM, Greider CW, Loyd JE: Telomerase mutations in families with idiopathic pulmonary fibrosis. $N$ Engl J Med 2007, 356:1317-1326.

6. Armanios M: Syndromes of telomere shortening. Annu Rev Genomics Hum Genet 2009, 10:45-61.

7. Alder JK, Chen JJ, Lancaster L, Danoff S, Su SC, Cogan JD, Vulto I, Xie M, Qi X, Tuder RM, Phillips JA, Lansdorp PM, Loyd JE, Armanios MY: Short telomeres are a risk factor for idiopathic pulmonary fibrosis. Proc Natl Acad Sci USA 2008, 105:13051-13056.

8. Hinz B, Phan SH, Thannickal VJ, Galli A, Bochaton-Piallat ML, Gabbiani G: The myofibroblast: One function, multiple origins. Am J Pathol 2007, 170:1807-1816.

9. Desmouliere A, Badid C, Bochaton-Piallat ML, Gabbiani G: Apoptosis during wound healing, fibrocontractive diseases and vascular wall injury. Int $J$ Biochem Cell Biol 1997, 29:19-30.

10. Wipff PJ, Rifkin DB, Meister JJ, Hinz B: Myofibroblast contraction activates latent tgf-beta1 from the extracellular matrix. J Cell Biol 2007, 179:1311-1323.

11. Desmouliere A, Chaponnier C, Gabbiani G: Tissue repair, contraction, and the myofibroblast. Wound Repair Regen 2005, 13:7-12.

12. Thannickal VJ, Horowitz JC: Evolving concepts of apoptosis in idiopathic pulmonary fibrosis. Proc Am Thorac Soc 2006, 3:350-356.
13. Thannickal VJ, Lee DY, White ES, Cui Z, Larios JM, Chacon R, Horowitz JC, Day RM, Thomas PE: Myofibroblast differentiation by transforming growth factor-beta1 is dependent on cell adhesion and integrin signaling via focal adhesion kinase. J Biol Chem 2003, 278:12384-12389.

14. Horowitz JC, Lee DY, Waghray M, Keshamouni VG, Thomas PE, Zhang H, Cui Z, Thannickal VJ: Activation of the pro-survival phosphatidylinositol 3kinase/akt pathway by transforming growth factor-beta1 in mesenchymal cells is mediated by p38 mapk-dependent induction of an autocrine growth factor. J Biol Chem 2004, 279:1359-1367.

15. Horowitz JC, Rogers DS, Sharma V, Vittal R, White ES, Cui Z, Thannickal VJ: Combinatorial activation of FAK and AKT by transforming growth factorbeta1 confers an anoikis-resistant phenotype to myofibroblasts. Cell Signal 2007, 19:761-771.

16. Vittal R, Horowitz JC, Moore BB, Zhang H, Martinez FJ, Toews GB, Standiford TJ, Thannickal VJ: Modulation of prosurvival signaling in fibroblasts by a protein kinase inhibitor protects against fibrotic tissue injury. Am J Pathol 2005, 166:367-375.

17. Hecker $L$, Vittal $R$, Jones $T$, Jagirdar $R$, Luckhardt TR, Horowitz JC, Pennathur S, Martinez FJ, Thannickal VJ: NADPH oxidase-4 mediates myofibroblast activation and fibrogenic responses to lung injury. Nat Med 2009, 15:1077-1081.

18. Carnesecchi S, Deffert C, Donati $Y$, Basset O, Hinz B, Preynat-Seauve O, Guichard C, Arbiser JL, Banfi B, Pache JC, Barazzone-Argiroffo C, Krause KH: A key role for nox4 in epithelial cell death during development of lung fibrosis. Antioxid Redox Signal 2011, 15:607-619.

19. Waghray M, Cui Z, Horowitz JC, Subramanian IM, Martinez FJ, Toews GB, Thannickal $\bigvee \mathrm{J}$ : Hydrogen peroxide is a diffusible paracrine signal for the induction of epithelial cell death by activated myofibroblasts. FASEB $J$ 2005, 19:854-856.

20. Pache JC, Carnesecchi S, Deffert C, Donati Y, Herrmann FR, BarazzoneArgiroffo C, Krause $\mathrm{KH}$ : Nox-4 is expressed in thickened pulmonary arteries in idiopathic pulmonary fibrosis. Nat Med 2011, 17:31-32.

21. Mittal M, Roth M, Konig P, Hofmann S, Dony E, Goyal P, Selbitz AC, Schermuly RT, Ghofrani HA, Kwapiszewska G, Kummer W, Klepetko W, Hoda MA, Fink L, Hanze J, Seeger W, Grimminger F, Schmidt HH, Weissmann N: Hypoxia-dependent regulation of nonphagocytic NADPH oxidase subunit Nox4 in the pulmonary vasculature. Circ Res 2007, 101:258-267.

doi:10.1186/1755-1536-5-S1-S23

Cite this article as: Thannickal: Mechanisms of pulmonary fibrosis: role of activated myofibroblasts and NADPH oxidase. Fibrogenesis \& Tissue Repair 2012 5(Suppl 1):S23.

\section{Submit your next manuscript to BioMed Central and take full advantage of:}

- Convenient online submission

- Thorough peer review

- No space constraints or color figure charges

- Immediate publication on acceptance

- Inclusion in PubMed, CAS, Scopus and Google Scholar

- Research which is freely available for redistribution 